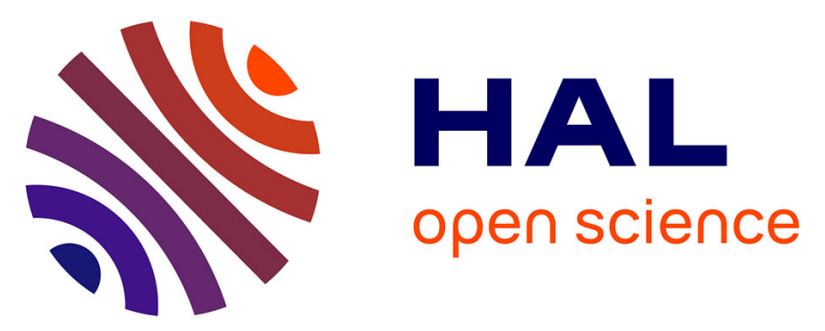

\title{
Use of an Emergency Department in Saint-Laurent du Maroni, French Guiana: Does Being Undocumented Make a Difference?
}

Anne Jolivet, Emmanuelle Cadot, Olivier Angénieux, Sophie Florence, Sophie Lesieur, Jacques Lebas, Pierre Chauvin

\section{To cite this version:}

Anne Jolivet, Emmanuelle Cadot, Olivier Angénieux, Sophie Florence, Sophie Lesieur, et al.. Use of an Emergency Department in Saint-Laurent du Maroni, French Guiana: Does Being Undocumented Make a Difference?. Journal of Immigrant and Minority Health, 2014, 16, pp.586-594. 10.1007/s10903-0139919-0 . inserm-00870068

\section{HAL Id: inserm-00870068 https://www.hal.inserm.fr/inserm-00870068}

Submitted on 16 Sep 2014

HAL is a multi-disciplinary open access archive for the deposit and dissemination of scientific research documents, whether they are published or not. The documents may come from teaching and research institutions in France or abroad, or from public or private research centers.
L'archive ouverte pluridisciplinaire HAL, est destinée au dépôt et à la diffusion de documents scientifiques de niveau recherche, publiés ou non, émanant des établissements d'enseignement et de recherche français ou étrangers, des laboratoires publics ou privés. 
Use of an emergency department in Saint-Laurent du Maroni, French Guiana: Does being undocumented make a difference?

Anne Jolivet ${ }^{1,2,3}$, Emmanuelle Cadot $^{1,2}$, Olivier Angénieux ${ }^{3}$, Sophie Florence ${ }^{1,2}$, Sophie Lesieur ${ }^{1,2}$, Jacques Lebas ${ }^{1,2,4}$, Pierre Chauvin ${ }^{1,2}$

1: INSERM, U707, Research Team on the Social Determinants of Health and Healthcare, Paris, France

2: Université Pierre et Marie Curie - Paris 06, UMR-S 707, Paris, France

3: Centre Hospitalier de l’Ouest Guyanais, Saint-Laurent du Maroni, French Guiana

4: AP-HP, Hôpital Saint-Antoine, Paris, France

\section{Corresponding author:}

Anne Jolivet

Centre Hospitalier de l'Ouest Guyanais

BP 245

97393 Saint-Laurent du Maroni, French Guiana

Phone: +33-5-94348912

Email: anne jolivet@yahoo.fr 


\section{Use of an emergency department in Saint-Laurent du Maroni, French Guiana: Does being undocumented make a difference?}

\section{ABSTRACT}

Few data exist on the health status and heath care utilization of the undocumented migrants in France. Data are particularly scarce in French overseas territories where this population is numerous. We aimed to describe the characteristics of undocumented patients who use the emergency department of Saint-Laurent du Maroni Hospital (SLMH) in French Guiana, and to identify factors associated with their subsequent hospitalization. In a random sample of 177 patients, we used logistic regression models to test the mediational role of health-care system utilization and medical characteristics at admission in the association between residency status and hospitalization. More than a quarter of patients $(27.7 \%)$ were undocumented migrants, who were subsequently hospitalized more often than the others $(\mathrm{OR}=3.11,95 \% \mathrm{CI}=[1.32-7.34])$. More-severe symptoms at admission, a poorer access to health insurance, a greater distance between their home and SLMH, and poorer French language skills partially explained this higher hospitalization rate. Despite the fact that France has instituted a specific insurance program for the undocumented, an increasing number of barriers to accessing health care is being reported for these people. Our results suggest that these obstacles have some impacts in the utilization of hospital care.

\section{KEY WORDS}

Undocumented migrants - Healthcare utilization - Health insurance - Mediational analysis - French Guiana 


\section{INTRODUCTION}

Undocumented migrants are one of the most vulnerable populations in Europe, and they often have poor health [1-4]. Studies on their access to care and their use of health-care systems are relatively rare, but they show that they face numerous obstacles in obtaining care $[3,5-8]$ even in countries like France that offer, at least theoretically, access to a broad range of care services for undocumented migrants [4]. Available data on undocumented migrants are even scarcer in French overseas territories where - because of their geographic situations and their proximities with far less developed countries this population is particularly numerous [9].

French Guiana is located in a humid equatorial zone of South America, bounded by Surinam and Brazil. The first French settlers arrived at the beginning of the 17th century. After being a French colony during almost 350 years, French Guiana became in 1946 a full-fledged overseas department of France, with the same legislation and social security system as in mainland France. Up until the early 1960s, the history of French Guiana was characterized by a problematic and insufficient human settlement. Over the last 50 years, the installation of a spatial center (today the European Space Agency's primary launch site) and a deepening development gap between this department and its neighboring countries have caused successive immigration waves (mainly from Brazil, Surinam and Haiti). In 2009, this department had 229,000 inhabitants, with a multiethnic population, and remains heavily dependent on mainland France for subsidies, trade and goods. Saint-Laurent du Maroni is its second most populous city, with 37500 inhabitants in 2009. Because, in part, of its geographical location (on the Maroni River, which forms the border with Surinam) and the economic disparity with its neighboring country, this city is a prime destination for migrants, some of whom stay, while others return or shuttle back and forth across the border. In 2008, the French Bureau of statistics indicates that immigrants accounted for $53.6 \%$ of the over- 15 population [10], but there are no official statistics available for the undocumented population. A general population study conducted in 2009 found that $26 \%$ of the adults (over 18 years of age) living in Saint-Laurent du Maroni were undocumented, 
despite having been in French Guiana for a long time [9]. The study also found that undocumented migrants presented with the worst health indicators.

Saint-Laurent du Maroni Hospital (SLMH) is the only source of secondary and emergency care in the cross-border area. There is a growing perception among health professionals, public authorities and local public opinion that people who are in French Guiana illegally constitute a heavy burden for this hospital [11-12]. Also many of them believe that people from Surinam cross the border to get medical care at this hospital [11-12]. A recent study found that the proportion of foreign migrants who had emigrated to or settled in French Guiana for health reasons (3.1\%) was low compared to the proportion of those who had done so for other reasons (the main one being economic) [13]. However, no study has ever been conducted to determine what percentage of the people who use this hospital are undocumented or from Surinam and if they have special health needs. We conducted a study in this hospital's ED, which sees 15000 patients a year. Our objectives were to:

- Describe the population that uses the SLMH's emergency department;

- Compare the patients' sociodemographic and medical characteristics and their use of the health-care system on the basis of their residency status; and

- Compare the hospitalization rate on the basis of residency status and analyze the factors that can explain any difference that might be found.

With regard to the last objective, we tested the hypothesis that certain patients' characteristics (medical and related to access to care) mediate the relationship between residency status and hospitalization, defining here a mediator as a third variable that helps explain how or why the independent variable predicts the outcome variable and that enables investigators to explore the mechanism behind the relationship between the independent variable and the outcome variables [14-15]. Our hypothesis was based on a social determinants of health's theoretical framework that position the legal status as a proximal determinant of health [16]. 


\section{METHODS}

\section{Study design}

An anonymous, cross-sectional, observational survey was conducted in the Saint-Laurent du Maroni Hospital's ED. All patients 16 years of age or older who presented to the ED for care were eligible. The exclusion criteria were participation in this study during a previous ED visit and having been triaged directly to the obstetrics department or to an outpatient visit with a general practitioner. To ensure the sample's representativeness and to take into account the variations in the number of visits to the emergency room according to the time of day and the day of the week, a random draw of time slots (12 a.m. to 7 a.m., 7 a.m. to 1 p.m., 1 p.m. to 7 p.m. and 7 p.m. to 12 a.m.) was performed in proportion to the average number of visits per time slot and per day (estimated from admission forms for two typical weeks of activity). For the purpose of surveying 150 patients, and with an estimated response rate of 75\%, 25 time slots were randomly selected over two 15-day periods in February and March 2009.

\section{Data Collection}

Two instruments were developed for this study: a patient questionnaire and a physician questionnaire. After the triage process, eligible patients were approached by interviewers who spoke the local languages (French, Guyanese Creole, Dutch, Brazilian and Nenguee) and who had been specially trained. The study's objectives were explained to the patients, and they were told that their participation in the study was completely voluntary and anonymous and would not affect the management of their care. Those who agreed to participate were then interviewed in the ED waiting room or one of the treatment areas. The patient questionnaire, which took approximately 15 minutes, was used to capture their demographics and socioeconomic status (gender, age, place of residence, education level, fluency in French, place of birth, nationality, and, in the case of foreigners, residency status), as well as their health-care system utilization in French Guiana (having or not having a regular family doctor, their health insurance status, and their perceived difficulties accessing health care). For 
health insurance status, we distinguished between patients who were covered either by the regular social security system or by “Aide Médicale d'État" (AME), a government-run insurance program specifically for undocumented migrants after their third month of residency in a French territory [17], and those who were not. The physician questionnaire was placed in the patient's file for completion by the attending physician. The medical variables were the patient's severity at admission, the main reason for visiting the ED (infectious disease, trauma, surgical problem, obstetrical problem, chronic illness, or other health problem), symptom duration, and the outcome (returned home or admitted). Severity at admission was assessed by the CCMU (a French acronym for "clinical classification for emergency care patients"), a 5-point scale widely and routinely used in many French EDs to assess a patient's clinical status, the severity of the problem and his or her prognosis (see Table 1) [18]. This protocol was approved by the institutional review board of the SLMH.

\section{Data Analysis}

The demographics, socioeconomic status, health care utilization and medical characteristics were compared between the individuals without a legal resident permit (referred to as "undocumented migrants" in the rest of this paper) and those with French (or European) citizenship or a resident permit. The qualitative variables were compared using the chi ${ }^{2}$ test, and the quantitative data were compared using the Student test, both with a threshold of 0.05 . To test the mediational hypothesis, a series of analyses were performed following the procedures outlined by Baron and Kenny [14]. First, factors associated with hospitalization were studied by fitting bivariate logistic regression models with the hospitalization outcome (yes/no) as the dependant variable and estimating odds ratios (ORs) and their $95 \%$ confidence intervals (95\% CIs). The independent variables that were significantly associated both with residency status and hospitalization were then considered potential mediators of the relationship between these two parameters. Subsequently, we tested all the potential mediators successively by including them simultaneously with residency status in a multiple logistic regression model as predictors of hospitalization. Complete mediation was when the initial variable (residency status) no longer affected the outcome (hospitalization) after the mediator was controlled for. For each model, we calculated the proportion of the reduction in the OR compared to the non-mediated model. 
These models were systematically adjusted for the following potential confounding variables: age, gender and education level. All the analyses were performed with Stata ${ }^{\circledR}$ software, version 10.0.

\section{RESULTS}

\section{Sample description}

During the randomly selected time slots, 355 patients presented to the SLMH's emergency department. Of them, 145 did not meet the eligibility criteria: 120 of them were under the age of 16 years, 17 were referred directly to a general practitioner, 2 were sent to the delivery room, and 6 came to the ED several times during the survey period. Of the 210 eligible patients, 9 (4.3\%) declined to participate and $24(11.4 \%)$ could not be interviewed (had left before the interview, were too ill to answer or were under arrest). The survey participation rate was therefore $84.3 \%$. More than half of the 177 patients included (52.5\%) visited during the morning time slot (7 a.m. to 1 p.m.), $28.8 \%$ during the afternoon time slot (1 p.m. to 7 p.m.), and $18.6 \%$ during the evening and night time slots (7 p.m. to 7 a.m.).

Females accounted for $56.5 \%$ of the sample. The median age was 32 years. An analysis of the nationalities, places of birth, and legal status for foreigners, revealed four subgroups in the study population: French nationals born in French Guiana (37.8\%); French nationals born outside French Guiana (18.1\%) - born in mainland France or in other overseas departments (13.0\%), or of foreign origin who had acquired French nationality (5.1\%) -; foreign nationals with a regular status in French Guiana (“documented foreigners” - 16,4\%); and lastly undocumented migrants (27.7\%). Among the documented foreigners and undocumented migrants, 59.0\% were born in Surinam.

\section{Comparison of undocumented migrants and other patients}

The demographic characteristics (age and gender) were not significantly different between the undocumented migrants and the French nationals and documented foreigners (Table 2). On the other 
hand, the undocumented migrants lived, for the most part, outside of Saint-Laurent du Maroni (49\% vs. $\left.20.3 \%, \mathrm{p}<10^{-3}\right)$, had a lower level of education $(37.5 \%$ had never gone to school or only had a primary school education vs. $\left.17.3 \%, \mathrm{p}<10^{-3}\right)$ and were less fluent in French $\left(25 \%\right.$ vs. $\left.86.7 \%, \mathrm{p}<10^{-3}\right)$. As for the health-care system utilization variables, fewer undocumented migrants indicated that they were followed on a regular basis by a physician $\left(37.5 \%\right.$ vs. $\left.78.7 \%, \mathrm{p}<10^{-3}\right)$ or had medical coverage $\left(27.1 \%\right.$ vs. $\left.88.2 \%, \mathrm{p}<10^{-3}\right)$. However, they did not say that they had more difficulty obtaining care than the others $(\mathrm{p}=0.63)$. As regards the medical variables, the undocumented migrants had higher baseline severity levels than the others $(20.4 \%$ were ranked CCMU 3 or 4 vs. $6.6 \%, p=0.03)$ and a higher hospitalization rate $(27.1 \%$ vs. $10.7 \%, \mathrm{p}=0.007)$. As for the reasons for consultation, only obstetrical problems were more frequent among the undocumented migrants $(\mathrm{p}=0.005)$.

\section{Factors associated with hospitalization}

The analysis of the factors associated with hospitalization (Table 3) shows that the undocumented patients were significantly more likely to be hospitalized $(\mathrm{OR}=3.11,95 \% \mathrm{CI}=[1.32-7.34])$ than other patients, as were women, patients who lived in other cities in French Guiana or who lived in Surinam, patients who were not fluent in French, those who did not have a regular family doctor or no health insurance, and those who had a surgical problem or a severe health problem (CCMU 3 or 4).

Based on the associations presented in Tables 2 and 3, the following variables were tested as potential mediators of the relationship between residency status and hospitalization: place of residence, fluency in French, regular family doctor status, health insurance status and severity at admission. The multivariate analyses (Table 4) concerned 166 patients $(6.2 \%$ of the questionnaires were excluded because of missing values for one or more of these variables). Once adjusted for age, gender and education level, the undocumented migrants were 4 times more likely to be hospitalized $(\mathrm{OR}=4.09$, $95 \% \mathrm{CI}=[1.49-11.24])$ than the other patients. The punctual estimate of this OR was reduced by half (and no longer statistically significant) when health insurance status was included in the model (see Model 4: $\mathrm{OR}=2.09,95 \% \mathrm{CI}=[0.58-7.49], \Delta \mathrm{OR}=48.9 \%)$. It was also reduced, but to a lesser extent, when, separately, the patient's place of residence (Model 1, $\Delta \mathrm{OR}=36.7 \%$ ), fluency in French (Model 
2, $\Delta \mathrm{OR}=32.3 \%$ ), level of severity at admission (Model $5, \Delta \mathrm{OR}=27.9 \%$ ) and regular family doctor status (Model 3, $\Delta \mathrm{OR}=19.3 \%$ ) were taken into account, in order of decreasing reduction. It should be noted that, because of our relatively small sample size, Model 3 was the only one where the association between residency status and hospitalization was not statistically significant. In addition, of all these potential mediating factors, only the place of residence and the severity of the case were significantly associated with our outcome. When all these factors were introduced into a single model at the same time, the OR in question (4.09) was reduced by $63.6 \%$.

\section{DISCUSSION}

Undocumented migrants accounted for $27.7 \%(95 \% \mathrm{CI}=[21.1-34.3])$ of the patients over 16 years of age who visited the SLMH's emergency department. Their health needs were different from those of the other patients: their cases were more severe upon their arrival at the ED, and they were hospitalized 3 times more often. The hypothesis of mediation by factors other than case severity is confirmed. Indeed, characteristics associated with their access to care and to their use of the healthcare system upstream from the ED visit, such as less access to medical coverage, the distance between their home and the point of care, and their being less fluent in French, seem to explain, partially but significantly, why the undocumented are hospitalized more often.

\section{Limitations and strengths}

This study has several limitations. The small sample size can be considered a weakness of the study, as it decreases its power and increases the likelihood of sampling error. Second, we placed in the same category documented foreigners and French nationals, as a previous study showed that these profiles did not differ in terms of health status [9]. Further analysis comparing the characteristics of these two subgroups showed that documented foreigners were older than French nationals (their mean ages were 42.5 years and 34.2 respectively, $\mathrm{p}=0.01$ ), were less fluent in French (4.0\% versus $44.8 \%)$, had lower education (44.8\% never been to school or primary level, versus $9.2 \%, \mathrm{p}<0.001)$ and had less often a 
health insurance $(27.6 \%$ versus $7.1 \%, \mathrm{p}=0.003)$. However their medical status at admission, health care utilization and hospitalization rate did not differ significantly.

Two of the study's strengths are the sampling method and the high participation rate, which yielded a representative sample of patients visiting the ED (including patients presenting during nights and weekends).

\section{Discussion of the major findings}

The proportion of undocumented individuals among the patients 16 years of age or older visiting this ED (27.7\%) was similar to the proportion of undocumented individuals among people aged 18 or older living in Saint-Laurent du Maroni (26\%, according to [9]). In contrast, a higher proportion of French nationals visited the ED (55.9\% vs. $45.8 \%$ of the population of Saint-Laurent du Maroni, $\mathrm{p}=0.001)$. Although delicate because the population area drawn from by the ED extends well beyond SaintLaurent du Maroni city limits, this comparison enables us to clearly put in perspective the notion of foreigners and undocumented individuals flowing into this ED. This is consistent with other studies that have shown that undocumented migrants use public health-care facilities significantly less than the rest of the population [19-21], even in countries like France (see below), where public policies have created the conditions for comprehensive health-care coverage for illegal immigrants [19].

Our study also shows that the needs of undocumented individuals who visit this ED are different. Their cases are more serious, and they are hospitalized more often. Other studies show that the undocumented are a population at risk for delaying seeking care and for doing so only at a more advanced stage of their illness [1], either because, living in precarious conditions, health is not their primary concern compared to other priorities and basic needs, or because they encounter particularly frequent obstacles in accessing care [8].

Only $27.1 \%$ of the undocumented individuals had a health insurance $(35.1 \%$ if the people living in Surinam are excluded). In French Guiana, as in mainland France, after their third month of uninterrupted stay in the country, undocumented migrants can theoretically access health care free of 
charge through AME, a specific, government-run, public health insurance system separate from the usual social security system, which is intended for French citizens and documented migrants only. In mainland France, several reports have shown the gap that exists between theoretical rights and actual rights to health care, due, among other things, to the complexity of the AME system, the numerous difficulties that people have in presenting the required documents, their lack of information about their rights, and the discriminatory attitudes and practices of some employees $[1,8,22]$. In French Guiana, these difficulties appear to be even worse [23-25]. We show here that not having health insurance seems to account for much of the observed association between being undocumented and being hospitalized. Indeed, the lack of health insurance can influence this association in two ways. First, it can do this upstream from the visit, since not having health insurance limits access to primary and preventive care, which could potentially obviate the need for hospitalization. Studies conducted in the U.S. [26] and Switzerland [27-28] have shown, in the context of prenatal care, that undocumented women lack access to important preventive measures. Not having health insurance can also influence caregiver practices. Very often, patients in this situation can only be managed in a hospital, and hospitalization can be a guarantee of adequate management. However, European [5-6, 29] and French [22] studies have shown that health professionals' attitudes toward undocumented patients can be characterized by discrimination (intentional or otherwise).

Other studies have shown that language problems and communication problems between patients and care providers can increase the risk of hospitalization [30], again because of care providers who prefer to ensure optimal management of patients by keeping them under observation. What is surprising is that while patients who are not fluent in French account for a total of $30.1 \%$ of this ED's users, it does not have any interpreters or cultural mediators. The care providers, who are not chosen on the basis of their language skills, can only call on multilingual coworkers on an as-needed basis, when they are present and available. Therefore, it is not unusual for there to be no one available to translate.

The place of residence also plays an important role in this context. It, too, is an access-to-care indicator. The geographical remoteness of a certain number of villages and access problems, particularly for the populations on the Maroni River, are obstacles to accessing care significantly 
associated with the likelihood of hospitalization. Once again, we can think of three reasons that could explain this high hospitalization rate: higher levels of severity (which would not perfectly fit the CCMU classification, since the association with the place of residence persisted after it was taken into account in the final model); the lack of health-care facilities in the border area in Surinam (some of these patients did, in fact, indicate that they had been referred to the SLMH by the physician at the health centre in Albina, a border town in Surinam); and the care providers' preference when only a follow-up on an outpatient basis is needed but which would prove difficult, given the distance (they prefer to hospitalize the patient instead of asking him or her to come back for a visit).

\section{CONCLUSION}

Undocumented migrants are underrepresented in the research literature on health care utilization in European countries in general and in European overseas territories in particular (even though many of the latter may be prone to illegal immigration pressure). Carried out in an environment that is emblematic of the particular attributes of such overseas border areas, this study sheds light on the health characteristics of and health care utilization by undocumented individuals who present to a particular ED. Our results show that much (nearly two-thirds) of their overuse of this ED can be explained by geographical and language problems, less access to primary care and more-severe clinical problems. As regards primary care, France nonetheless has, as have certain other European countries, instituted a specific (and free) insurance program for the undocumented. In practice, an increasing number of obstacles to accessing care are being reported for these people. Our results suggest that these difficulties accessing care are not without impact on the use of health-care facilities. Thus, rather than being immigration issue, the use of hospital care - particularly emergency care should be seen, paradoxically and counterintuitively, as a consequence of the undocumented exercising their right to health care. 


\section{ACKNOWLEDGEMENTS}

The study was funded by the Agence française de développement (AFD) within the framework of a collaborative contract with INSERM. The AFD did not participate in the writing of this article. 
Table 1: Clinical classification of emergency care patients (CCMU)

CCMU 1 Injury and/or functional prognosis considered stable. No further diagnostic or therapeutic procedures to be performed by the emergency department.

CCMU 2 Injury and/or functional prognosis considered stable. Decision made to perform further diagnostic or therapeutic procedures.

CCMU 3 Injury and/or functional prognosis considered at risk for worsening in the emergency department but not life-threatening.

CCMU 4 Life-threatening illness or injury. Management does not involve immediate resuscitation procedures.

CCMU 5 Life-threatening illness or injury. Management involves immediate resuscitation procedures. 
Table 2: Comparison of undocumented patients and patients who were French nationals and documented foreigners.

\begin{tabular}{|c|c|c|c|c|c|c|}
\hline & & \multicolumn{2}{|c|}{$\begin{array}{l}\text { French nationals } \\
\text { and documented } \\
\text { foreigners }\end{array}$} & \multicolumn{2}{|c|}{$\begin{array}{l}\text { Undocumented } \\
\text { migrants }\end{array}$} & \multirow[t]{2}{*}{$p$} \\
\hline & & $\mathrm{n}$ & $\%$ & $\mathrm{n}$ & $\%$ & \\
\hline \multicolumn{7}{|l|}{ Sociodemographic variables } \\
\hline \multirow[t]{2}{*}{ Gender } & Male & 60 & 46.9 & 17 & 34.7 & \multirow[t]{2}{*}{0.14} \\
\hline & Female & 68 & 53.1 & 32 & 65.3 & \\
\hline \multicolumn{2}{|l|}{ Age: Mean \pm SD } & \multicolumn{2}{|c|}{$36.1 \pm 16.4$} & \multicolumn{2}{|c|}{$36.6 \pm 15.1$} & 0.85 \\
\hline \multirow{3}{*}{ Place of birth } & French Guiana, mainland France or OST & 91 & 71.1 & 1 & 2.0 & \multirow[t]{3}{*}{$<0.001$} \\
\hline & Surinam & 19 & 14.8 & 30 & 61.2 & \\
\hline & Other & 18 & 14.1 & 18 & 36.7 & \\
\hline \multirow[t]{3}{*}{ Education level } & None or primary & 22 & 17.3 & 18 & 37.5 & \multirow[t]{3}{*}{$<0.001$} \\
\hline & Secondary & 30 & 23.6 & 20 & 41.7 & \\
\hline & Tertiary & 75 & 59.1 & 10 & 20.8 & \\
\hline \multirow[t]{3}{*}{ Place of residence } & Saint-Laurent du Maroni & 102 & 79.7 & 25 & 51.0 & \multirow[t]{3}{*}{$<0.001$} \\
\hline & Other city in French Guiana & 26 & 20.3 & 13 & 26.5 & \\
\hline & City in Surinam & 0 & 0 & 11 & 22.5 & \\
\hline \multirow[t]{2}{*}{ Fluent in French } & No & 17 & 13.3 & 36 & 75.0 & \multirow[t]{2}{*}{$<0.001$} \\
\hline & Yes & 111 & 86.7 & 12 & 25.0 & \\
\hline \multicolumn{7}{|c|}{ Variables pertaining to health-care system utilization } \\
\hline \multirow{2}{*}{ Regular family doctor status } & Had a regular family doctor & 100 & 78.7 & 18 & 37.5 & \multirow{2}{*}{$<0.001$} \\
\hline & Did not have a regular family doctor & 27 & 21.3 & 30 & 62.5 & \\
\hline \multirow[t]{2}{*}{ Health insurance status } & Had health insurance & 112 & 88.2 & 13 & 27.1 & \multirow[t]{2}{*}{$<0.001$} \\
\hline & Did not have health insurance & 15 & 11.8 & 35 & 72.9 & \\
\hline \multirow{2}{*}{$\begin{array}{l}\text { Perceived difficulties in } \\
\text { accessing health care }\end{array}$} & Access difficult & 71 & 56.4 & 24 & 52.2 & \multirow[t]{2}{*}{0.63} \\
\hline & Access easy & 55 & 43.7 & 22 & 47.8 & \\
\hline \multicolumn{7}{|l|}{ Medical variables } \\
\hline Main reason for visiting the & Infection & 26 & 23.0 & 9 & 18.8 & 0.12 \\
\hline \multirow{5}{*}{ ED } & Assault, accident or trauma & 25 & 22.1 & 8 & 16.7 & \\
\hline & Surgical problem & 6 & 5.3 & 4 & 8.3 & \\
\hline & Obstetrical problem & 5 & 4.4 & 8 & 16.7 & \\
\hline & Decompensation of a chronic disease & 4 & 3.5 & 3 & 6.3 & \\
\hline & Other health problem & 47 & 41.6 & 16 & 33.3 & \\
\hline Duration of symptoms & The same day or the previous evening & 56 & 44.8 & 16 & 33.3 & 0.33 \\
\hline & 2 to 7 days & 37 & 29.6 & 19 & 39.6 & \\
\hline & $>1$ week & 32 & 25.6 & 13 & 27.1 & \\
\hline Severity at admission & 1 & 25 & 20.7 & 7 & 14.3 & 0.03 \\
\hline (CCMU) & 2 & 88 & 72.7 & 32 & 65.3 & \\
\hline & 3 or 4 & 8 & 6.6 & 10 & 20.4 & \\
\hline Outcome & Returned home & 109 & 89.3 & 34 & 72.9 & 0.007 \\
\hline & Admitted & 13 & 10.7 & 13 & 27.1 & \\
\hline Total & & 128 & $100 \%$ & 49 & $100 \%$ & \\
\hline
\end{tabular}


Table 3: Factors associated with hospitalization: proportions of hospitalized patients by subgroup and odds ratio (univariate analysis).

\begin{tabular}{|c|c|c|c|c|c|}
\hline & & $\mathrm{n}$ & $\begin{array}{c}\% \\
\text { hospitalized }\end{array}$ & OR $(95 \% \mathrm{CI})$ & Global $p$ \\
\hline \multicolumn{6}{|c|}{ Sociodemographic variables } \\
\hline \multirow{2}{*}{ Gender } & Male & 74 & $21.6 \%$ & 1 & 0.048 \\
\hline & Female & 96 & $10.4 \%$ & $0.42(0.18-0.99)^{*}$ & \\
\hline \multirow[t]{3}{*}{ Age } & $16-25$ years & 55 & $9.1 \%$ & 1 & 0.19 \\
\hline & $25-40$ years & 60 & $18.3 \%$ & $2.24(0.73-6.94)$ & \\
\hline & $>40$ years & 55 & $18.2 \%$ & $2.22(0.71-6.99)$ & \\
\hline \multirow[t]{3}{*}{ Education level } & Tertiary & 81 & $13.6 \%$ & 1 & 0.24 \\
\hline & Secondary & 50 & $12.0 \%$ & $0.87(0.30-2.51)$ & \\
\hline & None or primary & 39 & $23.1 \%$ & $1.91(0.72-5.08)$ & \\
\hline \multirow[t]{2}{*}{ Residency status } & $\begin{array}{l}\text { French national or documented } \\
\text { foreigner }\end{array}$ & 122 & $10.7 \%$ & 1 & 0.009 \\
\hline & Undocumented migrant & 48 & $27.1 \%$ & $3.11(1.32-7.34)^{* *}$ & \\
\hline \multicolumn{6}{|c|}{ Variables relating to access to care } \\
\hline \multirow[t]{3}{*}{ Place of residence } & Saint-Laurent du Maroni & 122 & $9.0 \%$ & 1 & $<0.001$ \\
\hline & Other city in French Guiana & 37 & $27.0 \%$ & $3.74(1.44-9.70) * *$ & \\
\hline & City in Surinam & 11 & $45.5 \%$ & $8.41(2.20-32.07)^{* *}$ & \\
\hline \multirow[t]{2}{*}{ Fluent in french } & Yes & 117 & $10.3 \%$ & 1 & 0.009 \\
\hline & No & 53 & $26.4 \%$ & $3.14(1.34-7.38)^{* *}$ & \\
\hline \multicolumn{6}{|c|}{ Variables pertaining to health-care system utilization } \\
\hline \multirow{2}{*}{$\begin{array}{l}\text { Regular family } \\
\text { doctor status }\end{array}$} & Had a regular family doctor & 113 & $11.5 \%$ & 1 & 0.045 \\
\hline & Did not have a regular family doctor & 55 & $23.6 \%$ & $2.38(1.02-5.56)^{*}$ & \\
\hline \multirow{2}{*}{$\begin{array}{l}\text { Health insurance } \\
\text { status }\end{array}$} & Common right or AME & 120 & $10.0 \%$ & 1 & 0.004 \\
\hline & None & 49 & $28.6 \%$ & $3.60(1.52-8.51)^{* *}$ & \\
\hline \multirow{2}{*}{$\begin{array}{l}\text { Perceived difficulties } \\
\text { accessing health care }\end{array}$} & Access easy & 75 & $14.7 \%$ & 1 & 0.95 \\
\hline & Access difficult & 91 & $14.3 \%$ & $0.97(0.41-2.31)$ & \\
\hline \multicolumn{6}{|l|}{ Medical variables } \\
\hline \multirow{6}{*}{$\begin{array}{l}\text { Main reason for } \\
\text { visiting the ED }\end{array}$} & Infection & 34 & $14.7 \%$ & 1 & 0.83 \\
\hline & Assault, accident or trauma & 33 & $6.1 \%$ & $0.37(0.07-2.08)$ & \\
\hline & Surgical problem & 10 & $60.0 \%$ & $8.70(1.79-42.30)^{* *}$ & \\
\hline & Obstetrical problem & 13 & $23.1 \%$ & $1.74(0.35-8.63)$ & \\
\hline & Decompensation of a chronic disease & 7 & $14.3 \%$ & $0.97(0.09-9.84)$ & \\
\hline & Other health problem & 63 & $14.3 \%$ & $0.97(0.30-3.15)$ & \\
\hline \multirow{3}{*}{$\begin{array}{l}\text { Duration of } \\
\text { symptoms }\end{array}$} & The same day or the previous evening & 71 & $11.3 \%$ & 1 & 0.139 \\
\hline & 2 to 7 days & 54 & $14.8 \%$ & $1.37(0.48-3.92)$ & \\
\hline & $>1$ week & 41 & $22.0 \%$ & $2.21(0.78-6.29)$ & \\
\hline \multirow{3}{*}{$\begin{array}{l}\text { Severity at admission } \\
\text { (CCMU) }\end{array}$} & 1 & 32 & $3.1 \%$ & 1 & $<0.001$ \\
\hline & 2 & 119 & $10.9 \%$ & $3.80(0.48-30.22)$ & \\
\hline & 3 or 4 & 18 & $66.7 \%$ & $62.00(6.74-570.51)^{* * * *}$ & \\
\hline
\end{tabular}


Table 4: Change in the association between residency status and hospitalization when adjusting for potential mediating factors (logistic regression models systematically adjusted for age, gender and education level).

\begin{tabular}{|c|c|c|c|c|c|c|c|c|c|}
\hline & & $\mathrm{n}$ & $\begin{array}{l}\text { Model } 0 \\
\text { Unmediated model } \\
\text { aOR }(95 \% \mathrm{CI})\end{array}$ & $\begin{array}{l}\text { Model } 1 \\
\text { aOR }(95 \% \mathrm{CI})\end{array}$ & $\begin{array}{l}\text { Model } 2 \\
\text { aOR }(95 \% \mathrm{CI})\end{array}$ & $\begin{array}{l}\text { Model } 3 \\
\text { aOR }(95 \% \mathrm{CI})\end{array}$ & $\begin{array}{l}\text { Model } 4 \\
\text { aOR }(95 \% \mathrm{CI})\end{array}$ & $\begin{array}{l}\text { Model } 5 \\
\text { aOR }(95 \% \mathrm{CI})\end{array}$ & $\begin{array}{l}\text { Model } 6 \\
\text { Complete model } \\
\text { aOR }(95 \% \mathrm{CI})\end{array}$ \\
\hline \multirow[t]{2}{*}{ Residency status } & $\begin{array}{l}\text { French national or documented } \\
\text { foreigner }\end{array}$ & 122 & 1 & 1 & 1 & 1 & 1 & 1 & 1 \\
\hline & Undocumented migrant & 48 & $4.09(1.49-11.24)^{* * *}$ & $\begin{array}{l}2.59(0.79-8.41) \\
\Delta O R=36.7 \%\end{array}$ & $\begin{array}{l}2.77(0.86-8.94) \\
\Delta O R=32.3 \%\end{array}$ & $\begin{array}{l}\text { 3.30 (1.09-9.98)* } \\
\Delta O R=19.3 \%\end{array}$ & $\begin{array}{l}2.09(0.58-7.49) \\
\Delta O R=48.9 \%\end{array}$ & $\begin{array}{l}2.95(0.90-9.65) \\
\Delta O R=27.9 \%\end{array}$ & $\begin{array}{l}1.49(0.22-9.93) \\
\Delta O R=63.6 \%\end{array}$ \\
\hline Place of residence & $\begin{array}{l}\text { Saint-Laurent du Maroni } \\
\text { Other city in French Guiana } \\
\text { Surinam }\end{array}$ & $\begin{array}{l}122 \\
37 \\
11\end{array}$ & & $\begin{array}{l}1 \\
3.87(1.34-11.17)^{*} \\
5.31(1.00-28.21)^{*}\end{array}$ & & & & & $\begin{array}{l}1 \\
3.08(0.84-11.31) \\
3.52(0.43-28.83)\end{array}$ \\
\hline Fluent in French & $\begin{array}{l}\text { Yes } \\
\text { No }\end{array}$ & $\begin{array}{c}117 \\
53\end{array}$ & & & $\begin{array}{l}1 \\
2.26(0.63-8.05)\end{array}$ & & & & $\begin{array}{l}1 \\
1.46(0.21-10.07)\end{array}$ \\
\hline $\begin{array}{l}\text { Had a regular } \\
\text { doctor }\end{array}$ & $\begin{array}{l}\text { Yes } \\
\text { No }\end{array}$ & $\begin{array}{c}113 \\
55\end{array}$ & & & & $\begin{array}{l}1 \\
1.60(0.56-4.56)\end{array}$ & & & $\begin{array}{l}1 \\
0.68(0.13-3.54)\end{array}$ \\
\hline $\begin{array}{l}\text { Health insurance } \\
\text { status }\end{array}$ & $\begin{array}{l}\text { Common right or AME } \\
\text { None }\end{array}$ & $\begin{array}{c}120 \\
49\end{array}$ & & & & & $\begin{array}{l}1 \\
2.98(0.86-10.28)\end{array}$ & & $\begin{array}{l}1 \\
1.61(0.25-10.20)\end{array}$ \\
\hline $\begin{array}{l}\text { Severity at } \\
\text { admission } \\
\text { (CCMU) }\end{array}$ & $\begin{array}{l}1 \\
2 \\
3 \text { or } 4 \\
\end{array}$ & $\begin{array}{c}32 \\
119 \\
18 \\
\end{array}$ & & & & & & $\begin{array}{l}1 \\
3.57(0.41-30.73) \\
\mathbf{7 8 . 4 5}(\mathbf{7 . 0 0 - 8 7 8 . 5 6}) * * *\end{array}$ & $\begin{array}{l}1 \\
2.77(0.30-25.87) \\
\mathbf{5 5 . 1 3}(\mathbf{4 . 5 2}-\mathbf{6 7 3 . 0 6})^{* *}\end{array}$ \\
\hline
\end{tabular}




\section{REFERENCES}

1. Platform for International Cooperation on Undocumented Migrants (PICUM): Access to health care for undocumented migrants in Europe. Brussels; 2007.

2. World Health Organization (WHO): International migration, health \& human rights. Health \& Human Rights Publications Series Issue N4. Geneva; 2003.

3. Castaneda $\mathrm{H}$ : Illegality as risk factor: a survey of unauthorized migrant patients in a Berlin clinic. Soc Sci Med 2009; 68(8):1552-60.

4. Cuadra CB: Right of access to health care for undocumented migrants in EU: a comparative study of national policies. Eur J Public Health 2011. doi: 10.1093/eurpub/ckr049.

5. Jensen NK, Norredam M, Draebel T, Bogic M, Priebe S, Krasnik A: Providing medical care for undocumented migrants in Denmark: what are the challenges for health professionals? BMC Health Serv Res 2011; 11:154.

6. Biswas D, Kristiansen M, Krasnik A, Norredam M: Access to healthcare and alternative health-seeking strategies among undocumented migrants in Denmark. BMC Public Health 2011; 11:560.

7. Romero-Ortuno R: Access to health care for illegal immigrants in the EU: should we be concerned? Eur J Health Law 2004; 11:245-72.

8. Chauvin P, Parizot I, Simonnot N: Access to healthcare for the undocumented migrants in 11 European countries. Paris: Médecins du Monde European observatory on acces to healthcare; 2009.

9. Jolivet A, Cadot E, Florence S, Lesieur S, Lebas J, Chauvin P: Migrant health in French Guiana: Are undocumented immigrants more vulnerable? BMC Public Health 2012; 12(1):53.

10. INSEE: Institut National de la Statistique et des Etudes Economiques (French Bureau of Statistics)

[http://www.recensement.insee.fr/tableauxDetailles.action?zoneSearchField=SAINT+LAURE $\underline{\mathrm{NT}+\mathrm{DU}+\mathrm{MARONI} \& \text { codeZone }=97311-}$ COM\&idTheme $=9 \&$ idTableauDetaille $=22 \&$ niveauDetail $=1] .2008$.

11. Othily G, Buffet FN. Rapport de la commission d'enquête du Sénat sur l'immigration clandestine. Paris; 2006.

12. Jolivet A, Cadot E, Carde E, Florence S, Lesieur S, Lebas J, Chauvin P: Migrations, santé et soins en Guyane. Paris : Agence Française de développement; 2011.

13. Jolivet A, Florence S, Lebas J, Chauvin P: Migration, health, and care in French overseas territories. Lancet 2010; 376(9755):1827-8.

14. Baron RM, Kenny DA: The moderator-mediator variable distinction in social psychological research: conceptual, strategic, and statistical considerations. J Pers Soc Psychol 1986; 51(6):1173-82. 
15. Bennett JA: Mediator and moderator variables in nursing research: conceptual and statistical differences. Res Nurs Health 2000; 23(5):415-20.

16. Davies A, Basten A, Frattini C: Migration: A social determinant of migrants' health. EuroHealth 2010; 16(1):10-12.

17. Chevreul K, Durand-Zaleski I, Bahrami SB, Hernandez-Quevedo C, Mladovsky P: France: Health system review. Health Syst Transit 2010; 12(6):1-291.

18. Berthier F, Andreu M, Bourjac M, Baron D, Branger B, Turbide A: Analysis of cost and of non-medical care load of patients seen in an accident and emergency department--the importance of clinical classification of emergency patients. Eur J Emerg Med 1998; 5(2):23540.

19. Torres AM, Sanz B: Health care provision for illegal immigrants: should public health be concerned? J Epidemiol Community Health 2000; 54(6):478-9.

20. Reijneveld S, Verheij R, van Herten L, de Bakker D: Contacts of general practitioners with illegal immigrants. Scand J Public Health 2001; 29(4):308-13.

21. Vargas Bustamante A, Fang H, Garza J, Carter-Pokras O, Wallace SP, Rizzo JA, Ortega AN: Variations in healthcare access and utilization among Mexican immigrants: the role of documentation status. J Immigr Minor Health 2012; 14(1):146-55.

22. Larchanche S: Intangible obstacles: health implications of stigmatization, structural violence, and fear among undocumented immigrants in France. Soc Sci Med 2012; 74(6):858-63.

23. Carde E: Le système de soins français à l'épreuve de l'outre-mer: des inégalités en Guyane. Espace Populations Sociétés 2009; 1:175-189.

24. Médecins du Monde: Rapport 2007 de l'observatoire de l'accès aux soins de la mission France de Médecins du Monde. Paris; 2008.

25. Health for Undocumented Migrants and Asylum seekers (HUMA network): Access to health care for undocumented migrants and asylum seekers in 10 European countries. Paris; 2009.

26. Korinek K, Smith KR: Prenatal care among immigrant and racial-ethnic minority women in a new immigrant destination: exploring the impact of immigrant legal status. Soc Sci Med 2011; 72(10):1695-703.

27. Wolff H, Epiney M, Lourenco AP, Costanza MC, Delieutraz-Marchand J, Andreoli N, Dubuisson JB, Gaspoz JM, Irion O: Undocumented migrants lack access to pregnancy care and prevention. BMC Public Health 2008; 8:93.

28. Wolff H, Stalder H, Epiney M, Walder A, Irion O, Morabia A: Health care and illegality: a survey of undocumented pregnant immigrants in Geneva. Soc Sci Med 2005; 60(9):2149-54.

29. Goossens MC, Depoorter AM: Contacts between general practitioners and migrants without a residence permit and the use of "urgent" medical care. Scand J Public Health 2011; 39(6):64955 . 
30. Lee ED, Rosenberg CR, Sixsmith DM, Pang D, Abularrage J: Does a physician-patient language difference increase the probability of hospital admission? Acad Emerg Med 1998; $5(1): 86-9$. 